\title{
CORNUCOPIA HELICINA.
}

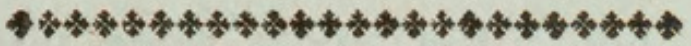

CHARACTER GENERICUS.

Animal Limax?

Testa spiralis, fragilis, anfractibus a se invicem remotis.

Apertura orbiculata, integra.

CHARACTER SPECIFICUS, Ec.

CORNUCOPIA fusco-flavescens, fasciis longitudinalibus fuscis.

CORNU COPIA\&. C. testa conica, turrita, anfractibus duobus liberis, apertura orbiculata.

Born. Test. M. Vind. p. 302.

Serpula Cornu copiæ.

Lin. Syst. Nat. Gmel. p. 3745.

Sel. 3. t. 40. f. 27 ?

Argenv. zoomorph. t. 9. f. 8. 2.

Cochleam hanc rarissimam, cujus vera magnitudo in tabula exprimitur, descripsit celeberrimus Born, in opere quod conscripsit de Testaceis Musei Vindobonensis. Habitu generali quam proxime affinis videtur 
videtur generibus Helicis et Turbinis; illi nempe facie similis; huic forma et apertura oris. Ab utrisque tamen in hoc differt, quod spiræ minime con. nectantur. De patria ambigitur. 
6i)

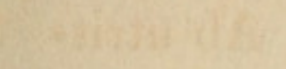

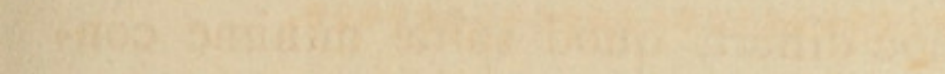




\section{.}

28
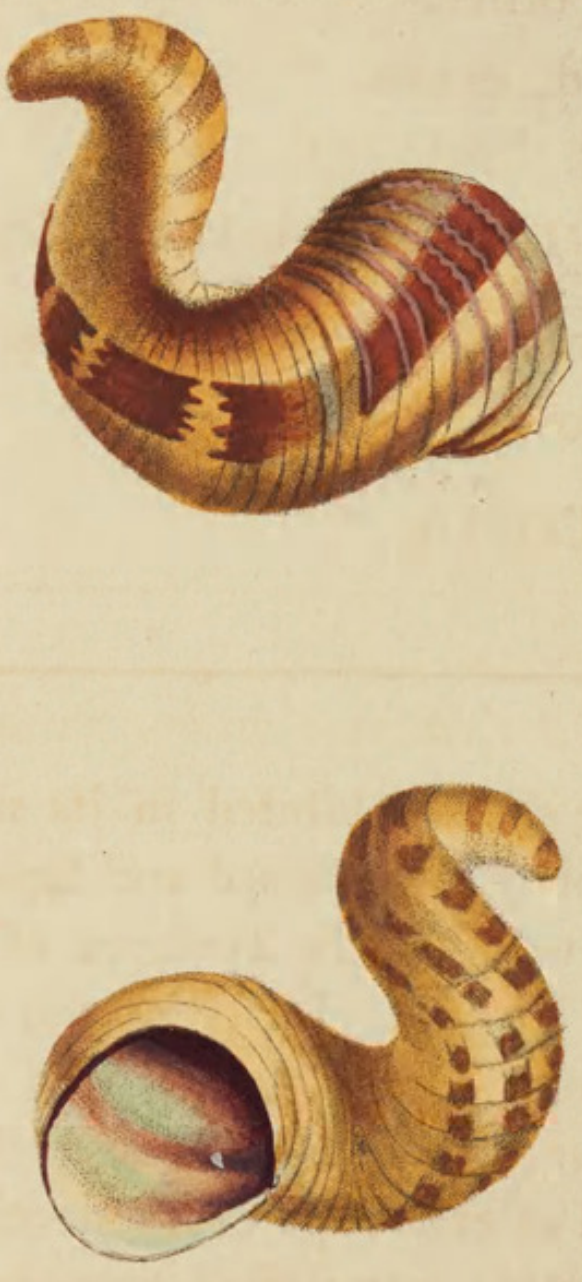


\section{HELICINE CORNUCOPIA.}

$4 * 4 * 4 * 4 * 4 * 4 * 4 * 4 * * 4$

GENERIC CHARACTER.

Animal allied to a Limax ?

Shell spiral, brittle, with the spires remote from each other.

Aperture round, entire.

\section{SPECIFIC CHARACTER, E̊C.}

Yellowish-brown CORNUCOPIA, with longitudinal brown bands.

\section{Snail CORNUCOPIA.}

The very rare shell exhibited in its natural size on the present plate is described and figured by $\mathrm{Ba}$ ron Born in his work on the Testacea of the Imperial Museum at Vienna. In its general appearance it makes an extremely near approach to the genera of Helix and Turbo; agreeing most in habit with the former, and in the shape of its mouth or opening with the latter; but differs from both in the produced and unconnected disposition of its spires. Its native country is unknown. 


\section{$2 \mathrm{BHL}$ Biodiversity Heritage Library}

Shaw, George. 1803. "The Helicine Cornucopia, Cornucopia helicina [PI. 568]." The Naturalist's Miscellany 14(CLXIII), https://doi.org/10.5962/p.311012.

View This Item Online: https://www.biodiversitylibrary.org/item/278723

DOI: https://doi.org/10.5962/p.311012

Permalink: https://www.biodiversitylibrary.org/partpdf/311012

\section{Holding Institution}

Museums Victoria

\section{Sponsored by}

Atlas of Living Australia

\section{Copyright \& Reuse}

Copyright Status: Public domain. The BHL considers that this work is no longer under copyright protection.

This document was created from content at the Biodiversity Heritage Library, the world's largest open access digital library for biodiversity literature and archives. Visit BHL at https://www.biodiversitylibrary.org. 